Article

\title{
Anti-Inflammation and Protective Effects of Anethum graveolens L. (Dill Seeds) on Esophageal Mucosa Damages in Reflux Esophagitis-Induced Rats
}

\author{
Hyeon-Hwa Nam ${ }^{1}$ (D) Li Nan ${ }^{2}$ (D) and Byung-Kil Choo ${ }^{3, *}$ \\ 1 Herbal Medicine Resources Research Center, Korea Institute of Oriental Medicine, Naju-si 58245, Korea; \\ namhh@kiom.re.kr \\ 2 Agricultural College, Yanbian University, Yanji 133002, China; nanli12@163.com \\ 3 Department of Crop Science \& Biotechnology, Jeonbuk National University, Jeonju 54896, Korea \\ * Correspondence: bkchoo@jbnu.ac.kr; Tel.: +82-63-270-2526
}

Citation: Nam, H.-H.; Nan, L.; Choo,

B.-K. Anti-Inflammation and

Protective Effects of Anethum

graveolens L. (Dill Seeds) on

Esophageal Mucosa Damages in

Reflux Esophagitis-Induced Rats.

Foods 2021, 10, 2500. https://

doi.org/10.3390/foods10102500

Academic Editor: Oliver Chen

Received: 2 September 2021

Accepted: 16 October 2021

Published: 18 October 2021

Publisher's Note: MDPI stays neutral with regard to jurisdictional claims in published maps and institutional affiliations.

Copyright: (c) 2021 by the authors. Licensee MDPI, Basel, Switzerland. This article is an open access article distributed under the terms and conditions of the Creative Commons Attribution (CC BY) license (https:// creativecommons.org/licenses/by/ $4.0 /)$

\begin{abstract}
Anethum graveolens L. (dill seeds) are important medicinal and functional foods in Europe and central and south Asia, often used as a seasoning in daily diets. Anethum graveolens L. seeds (AGS) are used to treat indigestion and have shown physiological activities such as those against hypoglycemia and gastroesophageal disease. This study explored the protective effects of AGS extract on mucosal damages and inflammation in reflux esophagitis rats. AGS inhibited cellular inflammation including NO production and the expression of inflammatory proteins (iNOS and COX2 etc.), cytokines (IL-1 $\beta$ and TNF- $\alpha$ ) and nuclear transfer factor related to NF- $k B$ signaling caused by LPS stimulation in vitro. Furthermore, reflux esophagitis-induced rats were used to observe the anti-inflammatory effect of AGS. Tissue staining and inflammation-related protein expression of rats with acute reflux esophagitis indicated that AGS improved this inflammatory response, such as COX-2 and TNF- $\alpha$ in mucosa. In conclusion, AGS have good physiological activity and the possibility of being used as a medicinal food and a functional resource for the prevention and therapy of gastroesophageal diseases.
\end{abstract}

Keywords: Anethum graveolens L.; anti-inflammation; NF-кB; reflux esophagitis

\section{Introduction}

Anethum graveolens L. seeds (AGS), which belong to the Umbeliferae family, have a strong spicy odor and an acrid taste and have been used as medicine, spices and for aromatic plants since ancient times [1-3]. This herb is used to treat stomachache and indigestion, as well as dyspepsia and gastrointestinal diseases [4,5]. In addition, this herb is extensively used in the food industry as a flavoring agent, including in Indian curry, ham, and other meat products [6-8]. The physiologically active constituents of AGS include tannins, limonene, Keaton, carvon and fatty acids and it is predicted that limonene, carvon, chlorogenic acid, and linoleic acid exhibit anti-inflammation and gastroprotection effects [9-13]. The gastroprotection effect of limonene was demonstrated by increased mucus production and anti-inflammatory response in rats. According to research focused on AGS, it shows hypolipidemic, hypoglycemic, and antibacterial bioactivity [12-15]. Although AGS have been used to treat gastrointestinal diseases, related studies have not investigated its involvement in anti-inflammation and gastroprotective effects.

Inflammation, a natural defense, is a response to harmful external stimulation such as physical damage, ultraviolet radiation, or pathogen invasion [14,16]. Various proinflammatory cytokines are secreted and produce a series of symptoms including redness, fever, and pain [17]. These symptoms are relieved with a reduction of inflammation. However, if the inflammatory reaction is too intense or prolonged, it can lead to tissue damage, serious disease, and even cancer [18]. Therefore, inhibiting its overgeneration is an important step in the treatment of various inflammatory diseases. 
Reflux esophagitis is one of the gastroesophageal reflux diseases that seriously affects patient life quality around the world [19]. This disease is receiving growing attention due to its increasing incidence and declining age of onset. Its occurrence is often caused by poor eating habits, smoking, or stress $[20,21]$. Destruction of the lower esophageal sphincter causes the stomach contents to flow back into the esophagus, creating inflammatory lesions that can lead to esophageal erosion and even esophageal cancer [22]. The main drugs used to treat inflammation are nonsteroidal anti-inflammatory drugs (NSAIDs). These drugs have anti-inflammatory, anti-rheumatic, analgesic, and antipyretic effects and are used clinically for symptoms such as rheumatoid arthritis, fever, and pain [23]. Although NSAIDs have good anti-inflammatory effects, long-term use can cause gastrointestinal dyspepsia, liver damage, allergies, and other adverse reactions [24]. Therefore, research is exploring natural plant sources that have good anti-inflammatory effects and no or few side effects [25]. To utilize the benefits of AGS for the digestive system and categorize it as a medicinal and functional food, research on its efficacy in digestive disorders is needed. This study demonstrated the therapeutic effects of AGS in reflux esophagitis-induced rats and the possible mechanisms of the responses.

\section{Materials and Methods}

\subsection{Extraction}

The AGS used in this study were purchased from Omniherb Company (Yakryeongro, Dongdaemun-gu, Seoul, Korea). The seeds were ground into powder with a mixer, $100 \%$ ethanol was added at a ratio of 1:10, and a multi heating mantle was used for three distillation extractions for $2 \mathrm{~h}$ each. The AGS extract was concentrated by a vacuum evaporator, lyophilized using a freeze-dryer, and stored at $-20^{\circ} \mathrm{C}$ until use. The $100 \mu \mathrm{g} / \mathrm{mL}$ of the AGS extracts were dissolved in DMSO as a stock solution, and were then used as a diluent in culture media for cell treatments.

\subsection{Chemical for HPLC Analysis}

Three iridoids, two phenylpropanoids, and one triterpenoid were detected in a $70 \%$ ethanolic extract of $A$. graveolens using HPLC-ELSD. Chlorogenic acid ( $\geq 98$ ) was purchased from KOC Biotech Corporation (Daejeon, Korea). Linoleic acid and elaidic acid were obtained from Aligent (Santa Clara, CA, USA) HPLC grade acetonitrile, ethanol, and distilled water were purchased from Merck (Darmstadt, Germany).

\subsection{HPLC Analysis of Anethum graveolens L. Seeds (AGS)}

Briefly, $16.63 \mathrm{mg}$ of AGS was dissolved in $1 \mathrm{~mL}$ of $100 \%$ ethanol, and filtered through a syringe filter. Three standards were prepared as stock solutions in $30 \%$ acetone in methanol. HPLC analysis was performed on a chromatographic system equipped with a separation module (e2695), a 2424 evaporative light-scattering detector (ELSD; Waters Co., Milford, MA, USA), and nitrogen gas generator (Genius, Peak Scientific Instruments Ltd., Scotland, UK). Confirmations of peaks in AGS chromatograms were processed using the Empower 3 program (Waters Co., Milford, MA, USA). Liquid chromatography separations were performed on a Luna C8(2) column $(5 \mu \mathrm{m}, 4.6 \times 250 \mathrm{~mm}$, Phenomenex Inc. (Torrance, CA, USA)) with $10 \mu \mathrm{L}$ injected volume and $0.9 \mathrm{~mL} / \mathrm{min}$ flow rate. The mobile phase consisted of $0.05 \%$ formic acid in distilled water (A) and acetonitrile (B), and the linear gradient program was as follows: $100 \% \mathrm{~A} \rightarrow 80 \% \mathrm{~A}$ (5 min), 50\% $\mathrm{A} \rightarrow 45 \% \mathrm{~A}(15 \mathrm{~min}), 45 \% \mathrm{~A} \rightarrow 30 \% \mathrm{~A}$ (17 min), 30\% A $\rightarrow 28 \%$ A (20 min), 28\% A $\rightarrow 7 \%$ A (40 min), 7\% A $\rightarrow 0 \%$ A (42 min), 0\% A isocratic mode for $47 \mathrm{~min}$. ELSD conditions were 50 of detector gain, 40 psi of nitrogen gas, and $50{ }^{\circ} \mathrm{C}$ of drift tube. All standard compounds were confirmed by comparing the retention time and $\lambda_{\max }$ of each compounds.

\subsection{Cell Culture}

Mouse mononuclear macrophage RAW264.7 cells were purchased from the Korea Cell Line Bank (Cancer Research Institute, Seoul National University, Chongno-gu, Seoul, Ko- 
rea). Cells were cultured in 10\% FBS medium with 100 units $/ \mathrm{mL}$ penicillin and $100 \mu \mathrm{g} / \mathrm{mL}$ streptomycin (Welgene, Namcheon-ro, Seoul, Korea) at $37^{\circ} \mathrm{C}$ and $5 \% \mathrm{CO}_{2}$ in an incubator with sufficient humidity.

\subsection{Cell Cytotoxicity and Morphological Changes}

Cells at a concentration of $5 \times 10^{5}$ cells $/ \mathrm{mL}$ in $100 \mu \mathrm{L}$ of medium were seeded in a 96-well plate and treated with AGS $(12.5,25$ and $50 \mu \mathrm{g} / \mathrm{mL})$, chlorogenic acid, linoleic acid, and elaidic acid $(3.13,6.25,12.5 \mu \mathrm{M})$ and LPS $(1 \mu \mathrm{g} / \mathrm{mL})$ (Sigma, St. Louis, MO, USA) for $18 \mathrm{~h}$. The cytotoxicity of AGS on RAW264.7 cells was determined using EZ-Cytox according to the technical manual. Cell morphology was observed using a microscope at $40 \times$.

\subsection{Nitric Oxide (NO) Production}

Cells at a concentration of $5 \times 10^{5}$ cells $/ \mathrm{mL}$ in $100 \mu \mathrm{L}$ of medium were seeded in a 96-well plate, pre-treated with AGS (12.5, 25 and $50 \mu \mathrm{g} / \mathrm{mL})$, chlorogenic acid, linoleic acid, and elaidic acid $(3.13,6.25,12.5 \mu \mathrm{M})$ for $1 \mathrm{~h}$, and then induced by LPS $(1 \mu \mathrm{g} / \mathrm{mL})$ for another $18 \mathrm{~h}$. The nitrite concentration in the cell culture medium was detected using the Griess method. Absorbance was measured with a multi-plate reader at $540 \mathrm{~nm}$. The nitrite content was calculated using the standard curve created.

\subsection{Inflammatory Cytokines Analysis}

The amounts of TNF- $\alpha$ and IL-1 $\beta$ (R\&D Systems, Minneapolis, MN, USA) in cell culture medium were measured using TNF- $\alpha$ and IL-1 $\beta /$ IL-1F2 immunoassay kits, respectively, according to the technical manual.

\subsection{Inflammatory Proteins Analysis}

Cells at a concentration of $1 \times 10^{6}$ cells $/ \mathrm{mL}$ in $2 \mathrm{~mL}$ of medium were seeded in a 6-well plate and were pre-treated with AGS $(25$ and $50 \mu \mathrm{g} / \mathrm{mL})$ for $1 \mathrm{~h}$. LPS $(1 \mu \mathrm{g} / \mathrm{mL})$ was then added to cells for $1 \mathrm{~h}$ and $18 \mathrm{~h}$. Cells were lysed with the lysis buffer used in our previous research. Proteins were collected and quantified with protein assay reagent to prepare a loading sample. The appropriate gel percentage for electrophoretic separation was selected according to protein size. The separated proteins were transferred to PVDF membranes and blocked with $5 \%$ skim milk at room temperature for $2 \mathrm{~h}$. The primary

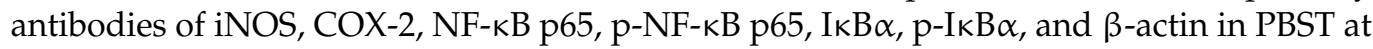
a ratio of 1:1000 were added to the membrane and were incubated at $4{ }^{\circ} \mathrm{C}$ overnight. Cells were incubated with secondary antibodies $(1: 10,000)$ at room temperature for $2 \mathrm{~h}$. Protein bands were observed using Bio-Rad imaging software.

\subsection{Immunofluorescence Assay}

Cells at a concentration of $2 \times 10^{5}$ cells $/ \mathrm{mL}$ in $2 \mathrm{~mL}$ of medium were plated in a 6-well plate with a $0.17 \mathrm{~mm}$ coverslip. Cells were pre-treated with AGS $50 \mu \mathrm{g} / \mathrm{mL}$ for $1 \mathrm{~h}$. To activate the NF- $\mathrm{KB}$ signaling pathway, LPS $(1 \mu \mathrm{g} / \mathrm{mL})$ was added to cells and incubated for $30 \mathrm{~min}$. Cells were fixed in $4 \%$ paraformaldehyde, and the cell membrane was destroyed by $0.5 \%$ Triton X-100 to allow antibodies to enter the nucleus. Antibodies were then blocked with $5 \%$ BSA containing $0.1 \%$ Triton X-100. Cells were incubated overnight at $4{ }^{\circ} \mathrm{C}$ with an NF- $\kappa$ B p65 primary antibody (Santa Cruz Biotechnology, Delaware Ave, Dallas, CA, USA) and 1\% BSA (1:200). Cells were incubated with a secondary antibody (Santa Cruz Biotechnology, Delaware Ave, Dallas, CA, USA) and 1\% BSA (1:1000) at room temperature in the dark for $2 \mathrm{~h}$. Finally, cell nuclear staining and mounting were conducted using histology mounting medium with DAPI (Sigma-Aldrich, St. Louis, MO, USA).

\subsection{Animal Management}

SD rats (7 weeks old and 200-220 g) were purchased from Hanil Experimental Animal Center (Samrye-ro, Wanju-gun, Jeonbuk, Korea). Rats were acclimated for one week in animal-specific breeding rooms with sufficient food and water. All experiments and the 
management of rats in this study were performed at the Jeonbuk National University in accordance with the regulations of the Animal Care and Use Committee of the Laboratory Animal Center of Jeonbuk National University (IACUC; CBNU 2020-011, date of approval, 17 February 2020).

\subsection{Reflux Esophagitis Rat Model}

At the end of the adaptation period, rats were randomly divided into four groups $(n=8)$. In group 1, the normal control group (Normal), rats did not undergo drug pretreatment or surgery to induce esophageal inflammation and injury. In group 2, the esophageal inflammation and injury control group (RE control), rats were pre-treated with physiological saline by gavage $2 \mathrm{~h}$ before the surgery. In group 3, the ranitidine treatment group, rats were pre-treated with ranitidine $(50 \mathrm{mg} / \mathrm{kg})$ by gavage $2 \mathrm{~h}$ before the surgery; and in group 4, the AGS treatment group, rats were pre-treated with AGS (75 mg/ $\mathrm{kg}$ ) by gavage $2 \mathrm{~h}$ before the surgery. Esophageal inflammation and injury were induced under respiratory anesthesia by ligating the pylorus and the junction of the forestomach and stomach body to cause repeated reflux of gastric contents to the esophagus to induce esophageal inflammation and injury. After $4.5 \mathrm{~h}$, all rats were anesthetized with ifran gas by a small animal anesthesia system, and the stomach and esophageal tissues were removed for analysis.

\subsection{Ratio of Esophageal Mucosa Damages}

The rat esophagus was cut longitudinally to expose the internal damage, and images were collected using a digital camera. The proportion of esophageal injury was analyzed using the Image J program. The calculation formula was the ratio of esophageal injury $(\%)=$ area of esophageal injury/total area of esophagus, as used in our previous study.

\subsection{Morphological Analysis in Esophgeal Mucosa}

Esophageal tissue was fixed with 4\% PFA, dehydrated, cleared, and prepared as a paraffin block. The tissue embedded in the paraffin block was cut into $5 \mu \mathrm{m}$ sections and stained with hematoxylin and eosin. Tissue morphology was observed using a Leica microscope.

\subsection{Extraction of Esophageal Tissue Proteins}

Esophageal tissue was ground into a homogenate with a cold cytoplasmic protein lysis buffer. The tube was placed on ice for $30 \mathrm{~min}$ and then centrifuged at $3000 \mathrm{rpm}$ for $3 \mathrm{~min}$. Supernatant with cytoplasmic protein was collected. The nuclear protein lysis buffer was added to re-suspend the pellet, and the solution was placed on ice for $30 \mathrm{~min}$ and then centrifuged at 13,000 rpm for $10 \mathrm{~min}$. Supernatant with nuclear protein was collected. The cytoplasmic and nuclear proteins were stored at $-80^{\circ} \mathrm{C}$ until use.

\subsection{Statistical Analysis}

Data in this study are expressed as mean \pm SD. One-way analysis of variance (ANOVA) and LSD multiple post-hoc comparisons were carried out by SPSS $12.0 \mathrm{~K}$. $p$ values $<0.05$ were considered significant.

\section{Results}

\subsection{Cell Morphological Changes}

Treatment with LPS not only causes cell morphology change into an irregular shape with unclear cell boundaries, but also induces inflammation and tissue damage. In this study, activation and cell morphology changes were induced by LPS compared with the normal group, while AGS treatment prevented these morphological changes (Figure 1A). 
A

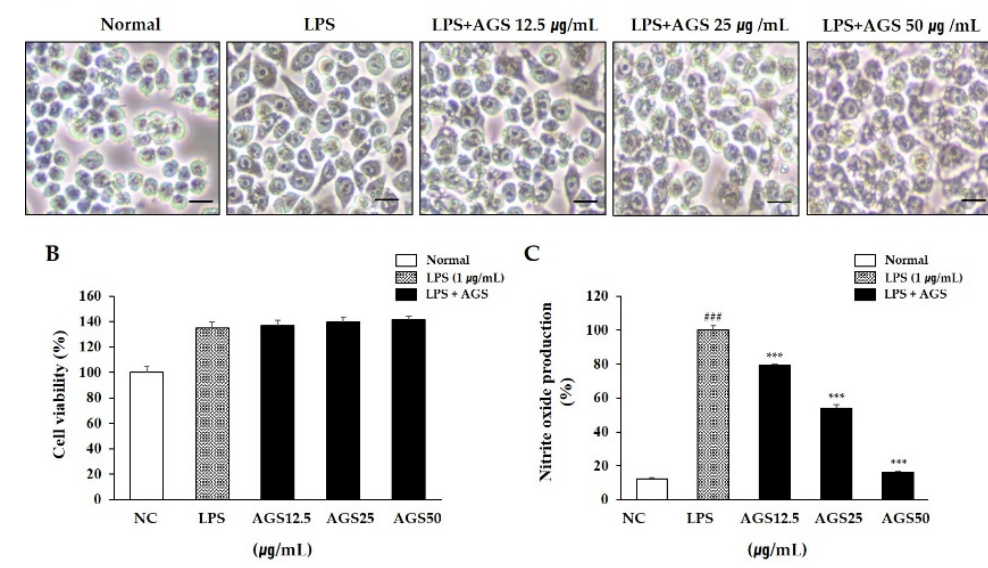

Figure 1. Effects of Anethum graveolens L. seeds (AGS) in cell cytotoxicity and nitrite oxide (NO) production. Cells treated with the AGS $(12.5,25,50 \mu \mathrm{g} / \mathrm{mL})$ and LPS $(1 \mu \mathrm{g} / \mathrm{mL})$ for $18 \mathrm{~h}$. Effect of AGS on morphological transformation (A), cell viability (B) and production of NO (C) in LPS-induced RAW264.7 cells. Scale bar was $200 \mu \mathrm{m}$. Data were expressed as mean \pm SD of duplicate experiment. Statistical analysis was performed for LPS compared with normal cells ( ${ }^{\# \#} p<0.001$ ) and each sample compared with LPS-induced cells (*** $p<0.001)$.

\subsection{Cytotoxicity and Nitrite Oxide (NO) Production}

Determining whether the extract has cytotoxicity is the basis for subsequent experimental research. In this study, a cytotoxicity assay kit was used to determine the effect of AGS on the viability of RAW264.7 cells (Figure 1B). In the concentration range of $12.5-50 \mu \mathrm{g} / \mathrm{mL}$, the cells in the AGS-treated group maintained high cell activity compared to the normal group, indicating the safety of AGS in RAW264.7 cells. When an inflammatory reaction occurs in a cell, the cell secretes excessive amounts of NO, inflammatory mediators that have an important relationship with the development and exacerbation of inflammation. In this study, NO production is significantly increased in only the LPS treatment group compared to the normal group. However, as a result of treatment with AGS, NO production was dose-dependently decreased, and more than $50 \%$ scavenging activity was exhibited at a concentration of $50 \mu \mathrm{g} / \mathrm{mL}$ compared with the LPS control group (Figure 1C).

\subsection{Inflammatory Cytokines Production}

When an inflammatory reaction occurs in a cell, the cell secretes excessive amounts of TNF- $\alpha$ and IL- $1 \beta$. These cytokines are closely related to the occurrence and development of inflammation. In this study, LPS stimulation increased TNF- $\alpha$ and IL-1 $\beta$ production compared with normal control. AGS pretreatment significantly inhibited the production of these substances, confirming that AGS effectively inhibits LPS-induced cell inflammation (Figure 2).

\subsection{Expression of Inflammatory Proteins}

A sudden increase of the inflammatory proteins iNOS and COX-2 is an important signal for cells to activate an inflammatory response. Therefore, inhibiting the expression of both can prevent further inflammatory responses. In this study, the expression levels of iNOS and COX-2 increased sharply after LPS stimulation. With AGS pretreatment, the increase in expression was inhibited significantly, especially at a AGS concentration of $50 \mu \mathrm{g} / \mathrm{mL}$ (Figure $3 \mathrm{~A}-\mathrm{C}$ ). 


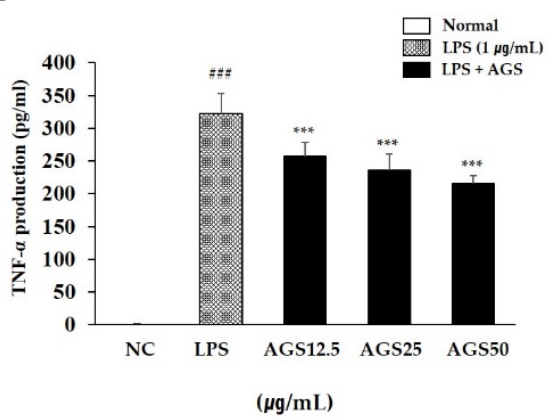

B

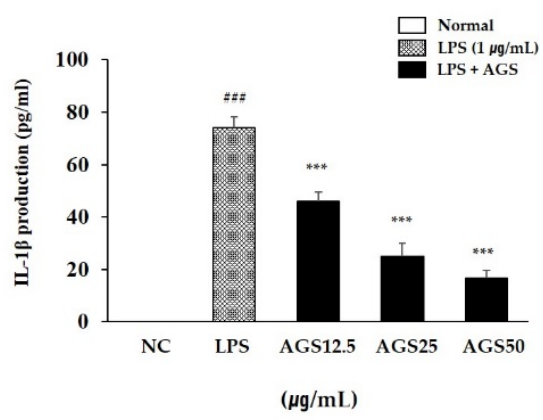

Figure 2. Inhibition effect of Anethum graveolens L. seeds (AGS) on cytokines production. Inhibition effect of AGS on production of TNF- $\alpha(\mathbf{A})$ and IL-1 $\beta$ (B) in LPS-induced RAW264.7 cells. Cells treated with the AGS $(12.5,25,50 \mu \mathrm{g} / \mathrm{mL})$ and LPS $(1 \mu \mathrm{g} / \mathrm{mL})$ for $18 \mathrm{~h}$. Data were expressed as mean $\pm \mathrm{SD}$ of duplicate experiment. Statistical analysis was performed for LPS compared with normal cells (\#\#\# $p<0.001)$ and each sample compared with LPS-induced cells $\left({ }^{* * *} p<0.001\right)$.

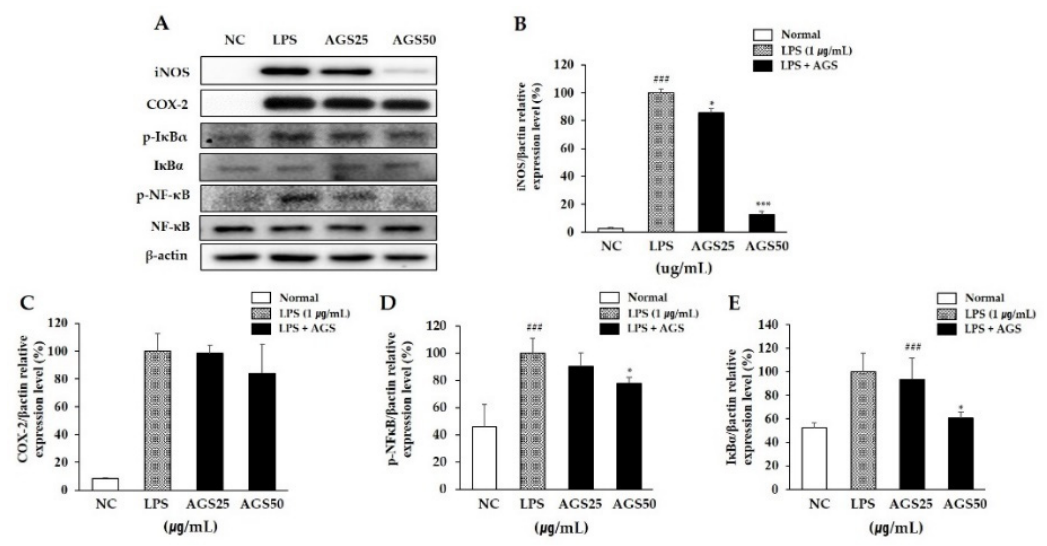

Figure 3. Inhibition effect of Anethum graveolens L. seeds (AGS) on expression of inflammatory proteins. Inhibition effect of AGS on expression level (A) of iNOS (B), COX-2 (C), p-NF-kB (D) and $\mathrm{p}-\mathrm{I} \kappa \mathrm{B} \alpha(\mathrm{E})$ proteins in LPS-induced RAW264.7 cells. Cells treated with the AGS $(12.5,25,50 \mu \mathrm{g} / \mathrm{mL})$ and LPS $(1 \mu \mathrm{g} / \mathrm{mL})$ for $1 \mathrm{~h}$ and $18 \mathrm{~h}$. Data were expressed as mean $\pm \mathrm{SD}$ of duplicate experiment. Statistical analysis was performed for LPS compared with normal cells ( ${ }^{\# \#} p<0.001$ ) and each sample compared with LPS-induced cells $\left({ }^{*} p<0.05\right.$ and $\left.{ }^{* *} p<0.001\right)$.

\subsection{Phosphorylation of NF- $k B$ and Ikba}

The NF- $\mathrm{kB}$ signaling pathway regulates the expression of inflammatory proteins and pro-inflammatory cytokines. Therefore, inhibiting the activation of NF- $\mathrm{kB}$ can suppress inflammation. In this study, LPS induced an increase in the phosphorylation of I $\mathrm{B} B \alpha$ and NF- $k B$ and in the transfer of NF- $k B$ into the nucleus. This suggests that the NF- $k B$ signaling pathway was activated to regulate cellular inflammation. AGS pretreatment significantly suppressed the activation of NF- $\mathrm{kB}$ by inhibiting the phosphorylation of IкB $\alpha$ (Figure 3A,D,E). These results indicate that AGS inhibits cell inflammation induced by LPS through regulation of the NF- $\mathrm{KB}$ signaling pathway.

\subsection{Immunofluorescensce Assay of NF-kB Nuclear Transfer}

As shown in Figure 4, NF- $\mathrm{kB}$ was expressed mostly in the cytosol in normal control cells. In the LPS-induced cells, NF- $\kappa B$ translocated into the nucleus, which was markedly reduced with AGS. 


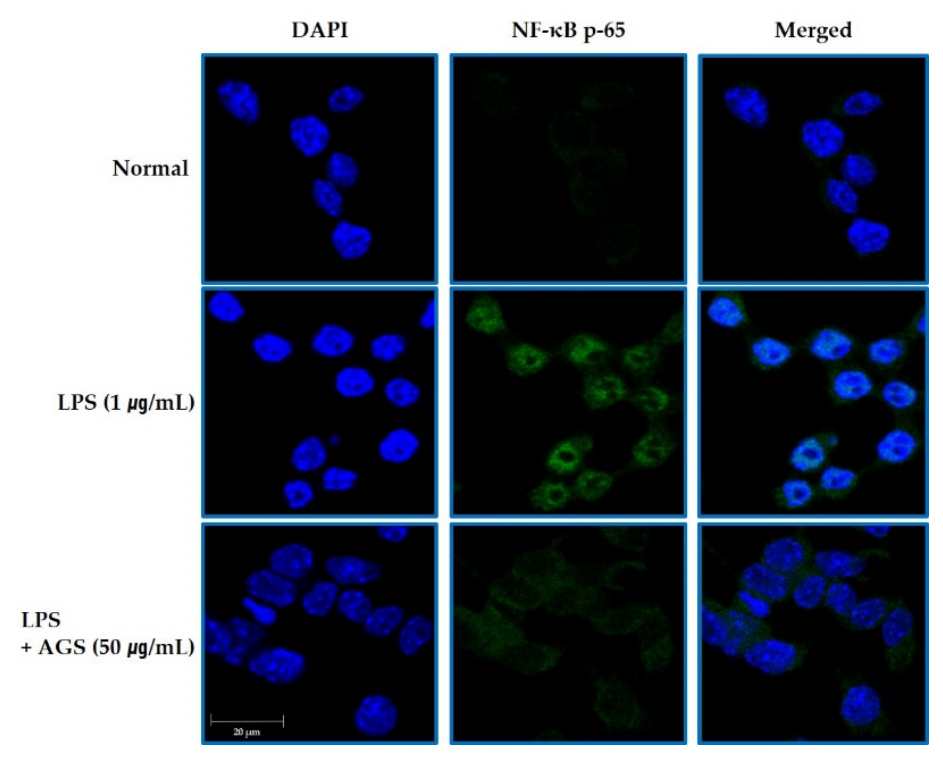

Figure 4. Inhibition the NF-kB Translocation by AGS. Inhibition effect of AGS nuclear transfer of NF- $\mathrm{kB}$ in LPS-induced RAW264.7 cells. Cells treated with the AGS $(12.5,25,50 \mu \mathrm{g} / \mathrm{mL})$ and LPS $(1 \mu \mathrm{g} / \mathrm{mL})$ for $1 \mathrm{~h}$.

\subsection{Esophageal Mucosal Damages Induced by Gastric Contents Reflux}

Gastric content reflux is one of the main features of reflux esophagitis. Repeated reflux causes esophageal mucosal damage and inflammation. In our study, continuous reflux of gastric contents induced by surgery led to extensive damage (including redness and hemorrhagic erosion) to the rats' esophagi (Figure 5). However, gavage with ranitidine (positive control drug, $50 \mathrm{mg} / \mathrm{kg}$ ) and AGS (75 mg/kg) $2 \mathrm{~h}$ before surgery effectively reduced esophageal tissue damages such as epithelial tissue destruction, redness and hemorrhage. Furthermore, AGS pre-treatment increased the $\mathrm{pH}$ of gastric contents and inhibited the secretion of gastric acid in RE rats.

A

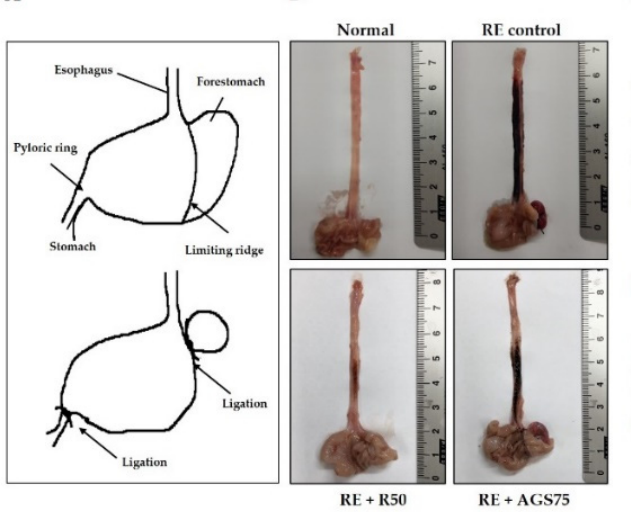

c

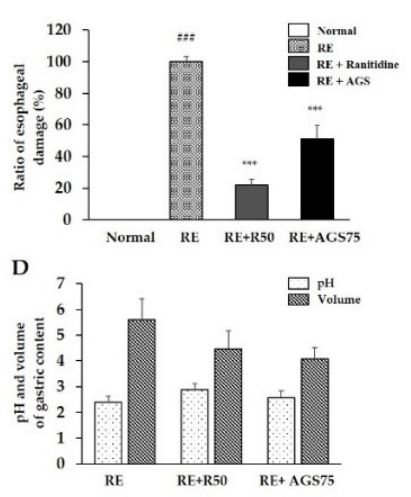

Figure 5. Observation of the esophageal mucosa damages. The sketch map of surgery of the reflux esophagitis rat model (A), representative microscopic image of the esophageal mucosa damage (B), ratio of esophageal damage (C), $\mathrm{pH}$ and volume of gastric contents (D), of the esophageal mucosa. Data were expressed as mean \pm SD of duplicate experiment. Statistical analysis was performed for LPS compared with normal cells (\#\#\# $p<0.001$ ) and each sample compared with LPS-induced cells $\left.{ }^{* * *} p<0.001\right)$.

\subsection{Histological Changes}

Histological observation is an important detection method for judging the integrity of tissue structure and the occurrence of tissue lesions. In this study, we observed a complete, tight, and clear esophageal tissue structure in the normal group (Figure 6). However, 
after gastric reflux, serious esophageal tissue lesions occurred, including tissue structure deformation, reduced tightness, and epithelial cell shedding. The lesions of esophageal tissue treated with ranitidine and AGS were greatly improved compared with RE control.
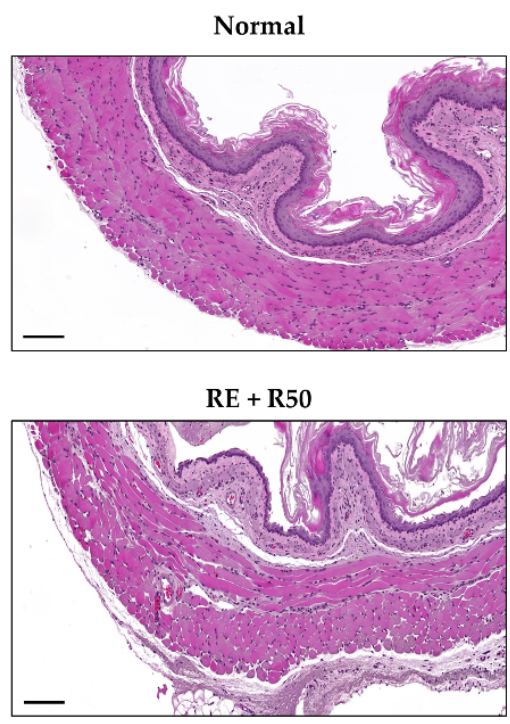

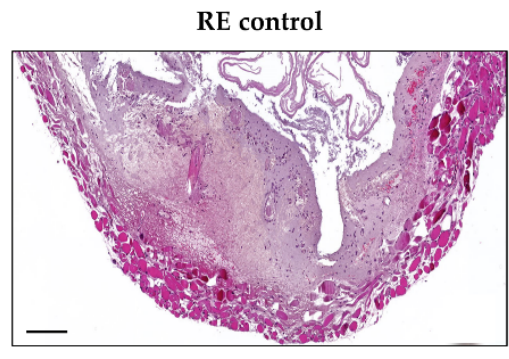

RE + AGS75

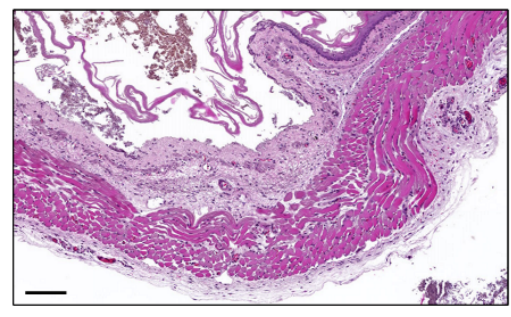

Figure 6. The histological observation on esophageal mucosa. Scale bar was $200 \mu \mathrm{m}$.

\subsection{Expression of Inflammatory Proteins in Esophageal Mucosa}

As an inducible enzyme, COX-2 is involved in regulating inflammation. TNF- $\alpha$ also play an important role in the inflammation process. Therefore, inhibiting the expression of COX-2 and TNF- $\alpha$ is one of the important factors that mediates the inflammatory response. In this study, repeated esophageal reflux caused esophageal inflammation and induced an increase in the expression of COX-2 and TNF- $\alpha$, while ranitidine and AGS gavage treatment significantly inhibited this expression in esophageal tissue (Figure 7).

A

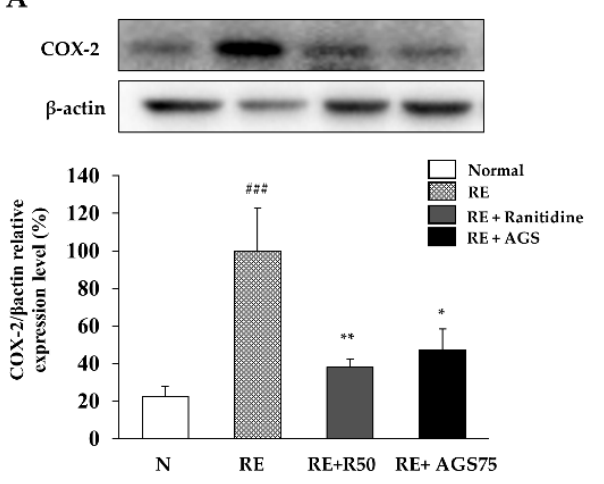

B

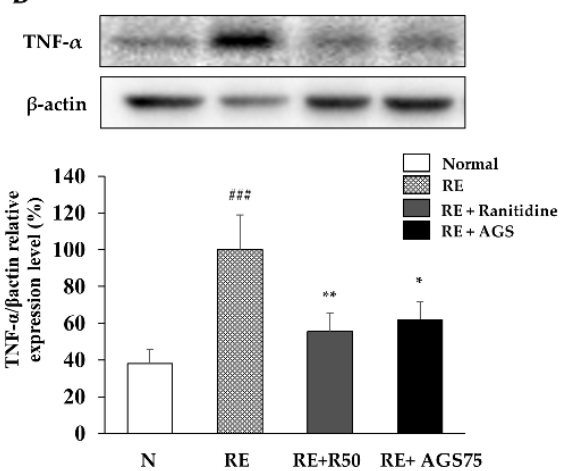

Figure 7. Expression of inflammatory proteins in esophagus. The expression of COX-2 (A) and TNF- $\alpha$ (B) in esophageal tissue. Data were expressed as mean \pm SD of duplicate experiment. Statistical analysis was performed for LPS compared with normal cells ( $\left.{ }^{\# \# \#} p<0.001\right)$ and each sample compared with LPS-induced cells ${ }^{*} p<0.05$ and $\left.{ }^{* *} p<0.01\right)$.

\subsection{Phytochemistry and Functional Properties of Anethum graveolens L. Seeds (AGS)}

Linoleic acid and elaidic acid has mainly been performed by GC with derivatization into methyl esters; however, the HPLC-ELSD method does not require derivatization [26]. Chlorogenic acid, linoleic acid, and elaidic acid were detected at approximately 10.157, 35.043 , and $39.483 \mathrm{~min}$, respectively. Amounts of three compounds were $11.805 \pm 0.409$, $30.957 \pm 0.625$, and $16.868 \pm 0.158 \mu \mathrm{g} / \mathrm{mg}$, respectively (Figure $8 \mathrm{~A}$ ). In order to confirm the inhibitory activity of the components on inflammation, the amount of NO produced 
in the RAW264.7 cells induced in inflammation was measured. The inhibitory effects of chlorogenic acid and elaidic acid were $57 \%$ and $54 \%$ in $125 \mu \mathrm{M}$, respectively. It was also confirmed that NO production was reduced by more than $25 \%$ at a concentration of $12.5 \mu \mathrm{M}$ by linoleic acid treatment and confirming that linoleic acid is the highest anti-inflammatory effects (Figure 8B).

A
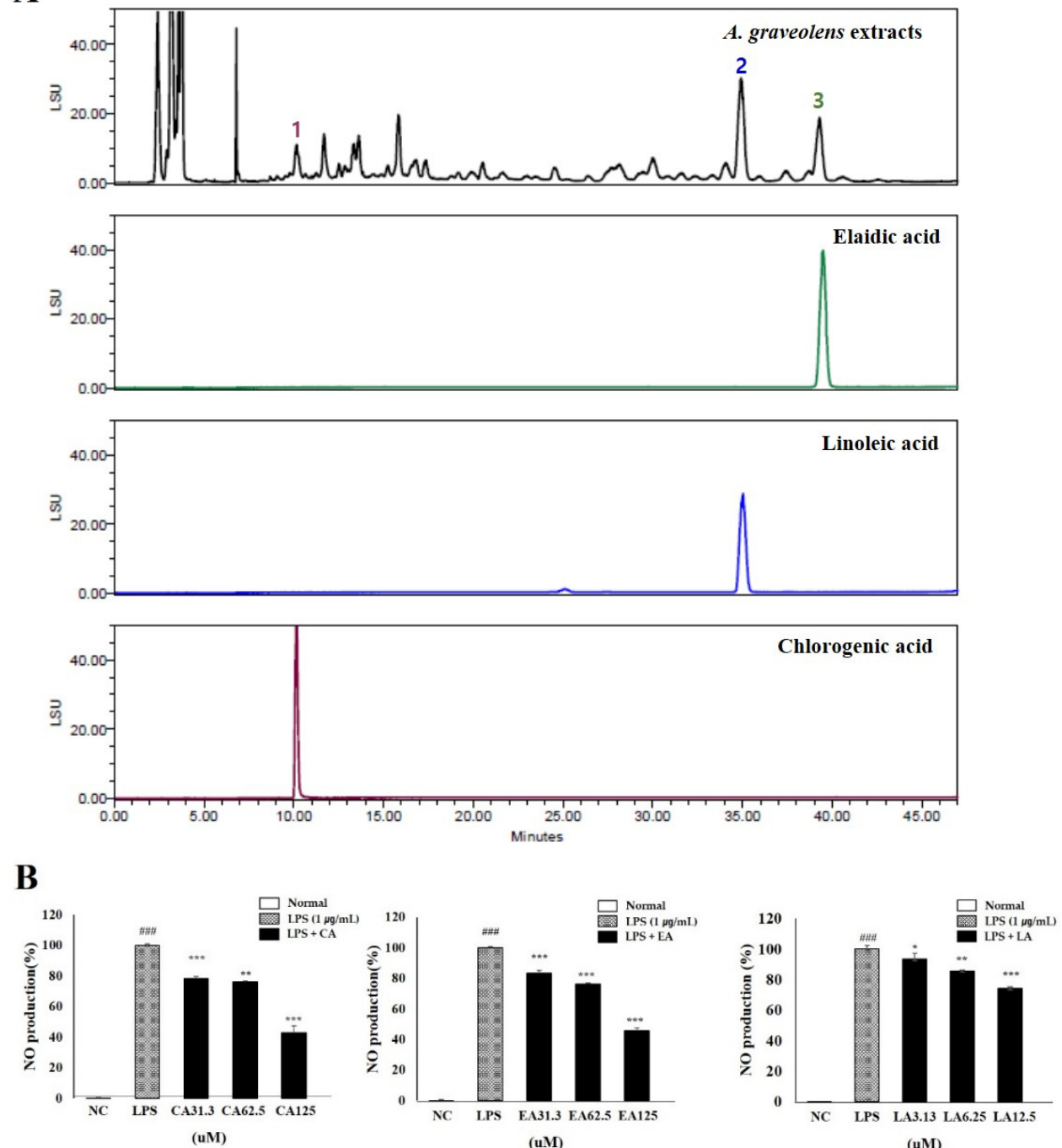

Figure 8. Phytochemistry and functional properties of Anethum graveolens seeds (AGS). Chromatogram of 70\% ethanolic extract of AGS (A); chlorogenic acid at $10.2 \mathrm{~min}$, linoleic acid at $35.1 \mathrm{~min}$, and elaidic acid at $39.5 \mathrm{~min}$ using HPLC-ELSD and Luna C8 (2) column. Anti-inflammatory effects of chlorogenic acid (CA), linoleic acid (LA), and elaidic acid (EA) in LPS-induced RAW 264.7 cells (B). Cells treated with the chlorogenic acid and elaidic acid $(31.3,62.5,125 \mu \mathrm{M})$, linoleic acid $(3.13,6.25$, $12.5 \mu \mathrm{M})$, and LPS $(1 \mu \mathrm{g} / \mathrm{mL})$ for $18 \mathrm{~h}$. Data were expressed as mean \pm SD of duplicate experiment. Statistical analysis was performed for LPS compared with normal cells ( ${ }^{\# \#} p<0.001$ ) and each sample compared with LPS-induced cells $\left({ }^{*} p<0.05,{ }^{* *} p<0.01\right.$ and $\left.{ }^{* * *} p<0.001\right)$.

\section{Discussion}

Reflux esophagitis is a disease that requires long-term medication and has a high recurrence rate. Both its incidence area and rate are increasing [27]. Because phytomedicine has the advantages of good curative outcomes and fewer side effects, recent trials to improve digestive disorder therapy have focused on traditional herbal medicine and functional foods. AGS is commonly used in foods and is a well-known traditional medicine for several diseases of the stomach, liver, kidney, and brain [11]. To further explore the 
physiological activity of AGS, we determined its anti-inflammatory activity and protection effects on esophageal mucosal damages in vitro and in vivo.

The LPS-induced macrophage RAW264.7 inflammatory model is commonly used to detect the anti-inflammatory activity of natural drugs [28,29]. RWA264.7 cells are also being used to research gastrointestinal mucosal damage and anti-inflammation mechanisms [30,31]. LPS, an endotoxin, transmits stimulation signals to cells by binding to intracellular functional LPS transmembrane receptors (Toll-like receptors), activating macrophages that cause the release of inflammatory mediators NO, TNF- $\alpha$, and IL- $1 \beta$ and leading to inflammation and tissue damage [32]. It plays a very important biological role in cardio-cerebrovascular, nerve, and immune regulation. Among inflammation mediators, NO produced by iNOS is considered one of the major problems [33]. We identified the anti-inflammation of AGS by inflammation response in LPS-induced RAW264.7 cells. As shown in Figure 1, NO produced by LPS stimulation was significantly inhibited without cytotoxicity by treatment AGS extracts. The expression of pro-inflammatory cytokines TNF- $\alpha$ and IL-1 $\beta$ were also increased by LPS treatment but decreased by AGS treatment in a dose dependent manner. Previous studies have shown that the expression of inflammatory proteins and pro-inflammatory cytokines is mediated by the NF- $\mathrm{kB}$ signaling pathway $[34,35]$. When an inflammatory reaction occurs in a cell, the inhibitory protein $\mathrm{I} \kappa \mathrm{B} \alpha$ is phosphorylated to release NF- $\mathrm{KB}$, which then undergoes nuclear transfer to regulate the expression of various inflammation-related genes such as cytokines, iNOS and COX-2 [36]. Therefore, if I $\kappa \mathrm{B} \alpha$ can effectively inhibit the activation of NF- $k \mathrm{~B}$, the occurrence and exacerbation of the inflammatory response can be suppressed. The result showed that AGS effectively inhibited the expression of iNOS, COX-2, I $\kappa \mathrm{B} \alpha$, and NF- $\mathrm{kB}$ and decreased translocation of the NF- $\mathrm{KB}$ into the nucleus in LPS-induced RAW 264.7 cells. In the present study, we demonstrated that AGS inhibited inflammation reaction by down-regulating pro-inflammatory mediators and suppressing the NF- $\mathrm{KB}$ signaling pathway.

Reflux esophagitis is induced by refluxed gastric acid and pepsin on esophageal epithelial cells. Chemical effects of refluxed gastric acid and pepsin lead to the acute inflammatory response and the death of surface epithelial cells in the esophagus [37,38]. According to several studies, to demonstrate the therapeutic effects of AGS on mucosal damages, we induced gastric content reflux to the esophagus by ligating the pylorus and the junction of the forestomach and stomach body [39]. Surgical induction of reflux produced apparent injury to the surface of the esophageal mucosa, including epithelial tissue destruction, redness and hemorrhage, compared to the normal group. However, these esophageal damages, such as redness and hemorrhagic lesions, were improved by about $50 \%$ in AGS $75 \mathrm{mg} / \mathrm{kg}$ groups. These visual symptoms are involved in the development of histopathological changes observed in esophageal mucosa. Our observations of histological changes to understand mucosal damages show that reflux esophagitis in this rat model involved the destruction and infiltration of inflammatory cells and edema in the epithelial layer, mucosa, and submucosa. These histopathological changes were alleviated by AGS administration. The changes in the damage index shown in this results demonstrated that short-term exposure to low $\mathrm{pH}$ acid and gastric contents of the esophageal mucosa caused local irritation and inflammation in the esophageal mucosa.

The acid-induced esophageal mucosal damage is predicted to promote an inflammatory process [37]. We measured the expression level of inflammatory protein to prove the inflammatory and anti-inflammatory response by AGS in damaged esophagus. COX-2 is an inducible enzyme with very low activity in normal tissue cells, but its expression level in inflammatory cells increases sharply, increasing PGE2 content at the inflammation site, resulting in inflammation and tissue damage [40]. The secretion of pro-inflammatory cytokines significantly increased at the site of epithelial injury due to acid reflux [37,41]. Submucosal and epithelial inflammation was associated with increased expression of proinflammatory cytokines. Actually, in epithelial immunostaining of acute reflux esophagitis form patients, TNF- $\alpha$ and COX-2 levels showed significant increases in mRNA [38]. In the 
esophageal mucosa of esophagitis rats, we observed a significant increase in the secretion of COX-2 and TNF- $\alpha$ with increasing chemical damage by acid in the esophageal mucosa.

The studies of chlorogenic acid and linoleic acid have reported the anti-inflammatory effects by reducing the activation of the NF- $\mathrm{kB}$ signaling pathway [42-44]. However, research on the NO inhibitory effect of elaidic acid has not been reported. We confirmed the presence of components reported to have anti-inflammatory activity in AGS extracts through HPLC-ELSD and Luna C8, and confirmed the anti-inflammatory activity of components in LPS induced RAW 264.7 cells. The result of the study of molecules in vivo showed a similar tendency to the expression level of the markers confirmed in vitro and to the results of morphological and histopathological analysis. Thus, the degree of damage to the esophageal mucosa is associated with the expression of pro-inflammatory proteins, and AGS is considered to protect the mucosa by inhibiting the inflammatory proteins in the esophageal tissue.

\section{Conclusions}

Our results confirmed the in vitro study of macrophages' induced inflammation, that AGS has great potential as an anti-inflammatory. The protective effects of AGS were also demonstrated in an esophagitis-induced rat model by regulating the epithelial inflammatory response. Through the results of this study, we illustrate the protective effects of AGS against esophageal injury by regulating expression levels of COX-2 and TNF- $\alpha$ in esophageal tissue. Therefore, we believe that AGS has good physiological activity and can be used as a functional food or resource in the industry for the prevention and therapy of gastroesophageal diseases.

Author Contributions: H.-H.N. and L.N. are the co-first author, Conceptualization, B.-K.C.; methodology, H.-H.N. and L.N.; software, H.-H.N. and L.N.; validation, H.-H.N. and L.N.; writing-original draft preparation, H.-H.N. and L.N.; writing—review and editing, B.-K.C.; visualization, L.N.; supervision, B.-K.C.; project administration, B.-K.C.; funding acquisition, B.-K.C. All authors have read and agreed to the published version of the manuscript.

Funding: This research was funded by "Cooperative Research Program for Agriculture Science \& Technology Development (Project No. PJ0142272020)" Rural Development Administration, Republic of Korea. Also, this paper was supported by research funds of Jeonbuk National University in 2020.

Institutional Review Board Statement: All experiments and the management of rats in this study were performed at the Jeonbuk National University in accordance with the regulations of the Animal Care and Use Committee of the Laboratory Animal Center of Jeonbuk National University (IACUC; CBNU 2020-011, date of approval: 17 February 2020).

Informed Consent Statement: Not applicable.

Data Availability Statement: Not applicable.

Conflicts of Interest: The authors declare no conflict of interest.

\section{References}

1. Mohammed, F.A.; Elkady, A.I.; Syed, F.Q.; Mirza, M.B.; Hakeem, K.R.; Alkarim, S. Anethum graveolens (dill)—A medicinal herb induces apoptosis and cell cycle arrest in $\mathrm{HepG}_{2}$ cell line. J. Ethnopharmacol. 2018, 219, 15-22. [CrossRef]

2. Talebi, F.; Malchi, F.; Abedi, P.; Jahanfar, S. Effect of dill (Anethum graveolens Linn) seed on the duration of labor: A systematic review. Complement Ther. Clin. Pract. 2020, 41, 101251. [CrossRef]

3. Badar, N.; Arshad, M.; Farooq, U. Characteristics of Anethum graveolens (umbelliferae) seed oil: Extraction, composition and antimicrobial activity. Int. J. Agri. Biol. 2008, 10, 329-332.

4. Li, Z.; Xue, Y.; Li, M.; Guo, Q.; Sang, Y.; Wang, C.; Luo, C. The antioxidation of different fractions of Dill (Anethum graveolens) and their influences on cytokines in macrophages RAW264.7. J. Oleo. Sci. 2018, 67, 1535-1541. [CrossRef]

5. Chen, Y.; Zeng, H.; Tian, J.; Ban, X.; Ma, B.; Wang, Y. Antifungal mechanism of essential oil from Anethum graveolens seeds against Candida albicans. J. Med. Microbiol. 2013, 62, 1175-1183. [CrossRef] [PubMed]

6. Hosseinzadeh, H.; Karimi, G.R.; Ameri, M. Effects of Anethum graveolens L. seed extracts on experimental gastric irritation models in mice. BMC Pharmacol. 2002, 2, 21. [CrossRef] 
7. Eshwar, S.K.R.; Jain, V.; Manvi, S.; Kohli, S.; Bhatia, S. Comparison of Dill seed oil mouth rinse and chlorhexidine mouth rinse on plaque levels and gingivitis-A double blind randomized clinical trial. Open Dent. J. 2016, 10, 207-213. [CrossRef] [PubMed]

8. Kaur, N.; Chahal, K.K.; Kumar, A.; Singh, R.; Bhardwaj, U. Antioxidant activity of Anethum graveolens L. essential oil constituents and their chemical analogues. J. Food Biochem. 2019, 43, e12782. [CrossRef] [PubMed]

9. Velioglu, Y.S.; Mazza, G.; Gao, L.; Oomah, B.D. Antioxidant activity and total phenolics in selected fruits, vegetables, and grain products. J. Agric. Food Chem. 1998, 46, 4113-4117. [CrossRef]

10. Zeng, H.; Tian, J.; Zheng, Y.; Ban, X.; Zeng, J.; Mao, Y.; Wang, Y. In vitro and in vivo activities of essential oil from the seed of Anethum graveolens L. against Candida spp. Evid. Base Complement Alternat. Med. 2011, 659704. [CrossRef]

11. Naseri, M.; Mojab, F.; Khodadoost, M.; Kamalinejad, M.; Davati, A.; Choopani, R.; Hasheminejad, A.; Bararpoor, Z.; Shariatpanahi, S.; Emtiazy, M. The study of anti-inflammatory activity of oil-based Dill (Anethum graveolens L.) extract used topically in formalin-induced inflammation male rat paw. Iran J. Pharm. Res. 2012, 11, 1169-1174.

12. Schepp, W.; Steffen, B.; Ruoff, H.J.; Schusdziarra, V.; Classen, M. Modulation of rat gastric mucosal prostaglandin E2 release by dietary linoleic acid: Effects on gastric acid secretion and stress-induced mucosal damage. Gastroenterology 1988, 95, 18-25. [CrossRef]

13. Shimoyama, A.T.; Santin, J.R.; Machado, I.D.; de Oliveira e Silva, A.M.; de Melo, I.L.; Mancini-Filho, J.; Farsky, S.H. Antiulcerogenic activity of chlorogenic acid in different models of gastric ulcer. Naunyn. Schmiedebergs. Arch. Pharmacol. 2013, 386, 5-14. [CrossRef]

14. de Souza, M.C.; Vieira, A.J.; Beserra, F.P.; Pellizzon, C.H.; Nóbrega, R.H.; Rozza, A.L. Gastroprotective effect of limonene in rats: Influence on oxidative stress, inflammation and gene expression. Phytomedicine 2019, 53, 37-42. [CrossRef]

15. Goodarzi, M.T.; Khodadadi, I.; Tavilani, H.; Oshaghi, E.A. The role of Anethum graveolens L. (Dill) in the management of diabetes. J. Trop. Med. 2016, 2016, 1098916. [CrossRef] [PubMed]

16. Fullerton, J.N.; Gilroy, D.W. Resolution of inflammation: A new therapeutic frontier. Nat. Rev. Drug Discov. 2016, 15, 551-567. [CrossRef] [PubMed]

17. Hu, T.Y.; Ju, J.M.; Mo, L.H.; Ma, L.; Hu, W.H.; You, R.R.; Chen, X.Q.; Chen, Y.Y.; Liu, Z.Q.; Qiu, S.Q.; et al. Anti-inflammation action of xanthones from Swertia chirayita by regulating COX-2/NF-kB/MAPKs/Akt signaling pathways in RAW 264.7 macrophage cells. Phytomedicine 2019, 55, 214-221. [CrossRef] [PubMed]

18. Diakos, C.I.; Charles, K.A.; McMillan, D.C.; Clarke, S.J.; Charles, K.A.; McMillan, D.C.; Clarke, S.J. Cancer-related inflammation and treatment effectiveness. Lancet Oncol. 2014, 15, 493-503. [CrossRef]

19. Kellerman, R.; Kintanar, T. Gastroesophageal Reflux Disease. Prim. Care 2017, 44, 561-573. [CrossRef]

20. Surdea-Blaga, T.; Negrutiu, D.E.; Palage, M.; Dumitrascu, D.L. Food and gastroesophageal reflux disease. Curr. Med. Chem. 2019, 26, 3497-3511. [CrossRef]

21. Mikami, D.J.; Murayama, K.M. Physiology and pathogenesis of gastroesophageal reflux disease. Surg. Clin. N. Am. 2015, 95, 515-525. [CrossRef] [PubMed]

22. Chen, J.T.; Brady, P. Gastroesophageal reflux disease pathophysiology, diagnosis, and treatment. Gastroenterol. Nurs. 2019, 42, 20-28. [CrossRef]

23. Díaz-Gonzále, F. NSAIDs: Learning new tricks from old drugs. Eur. J. Immunol. 2015, 45, 679-686. [CrossRef] [PubMed]

24. Haley, R.M.; von Recum, H.A. Localized and targeted delivery of NSAIDs for treatment of inflammation: A review. Exp. Biol. Med. 2019, 244, 433-444. [CrossRef] [PubMed]

25. Tsai, W.H.; Yang, C.C.; Li, P.C.; Chen, W.C.; Chien, C.T. Therapeutic potential of traditional chinese medicine on inflammatory diseases. J. Tradit. Complement Med. 2013, 3, 142-151. [CrossRef]

26. Kim, H.S.; Moon, B.C.; Yang, S.G.; Song, J.H.; Chun, J.M.; Kwon, B.I.; Lee, A.Y. Determination of fatty acids in the seeds of Lepidium apetalum Willdenow, Descurainia sophia (L.) Webb ex Prantl, and Draba nemorosa L. by ultra-high-performance liquid chromatography equipped with a charged aerosol detector. J. Liq. Chromatogr. Relat. Technol. 2019, 42, 128-136. [CrossRef]

27. Sandhu, D.S.; Fass, R. Current Trends in the Management of Gastroesophageal Reflux Disease. Gut Liver 2018, 15, 7-16. [CrossRef]

28. Baskaran, A.; Chua, K.H.; Sabaratnam, V.; Ram, M.R.; Kuppusamy, U.R. Pleurotus giganteus (Berk. Karun \& Hyde), the giant oyster mushroom inhibits NO production in LPS/H2O2 stimulated RAW 264.7 cells via STAT 3 and COX-2 pathways. BMC Complement Altern. Med. 2017, 17, 40. [CrossRef]

29. Wei, X.; Zhang, L.; Zhang, R.; Wu, R.; Si, D.; Ahmad, B.; Petitte, J.N.; Mozdziak, P.E.; Li, Z.; Guo, H.; et al. A highly efficient hybrid peptide ameliorates intestinal inflammation and mucosal barrier damage by neutralizing lipopolysaccharides and antagonizing the lipopolysaccharide-receptor interaction. FASEB J. 2020, 34, 16049-16072. [CrossRef]

30. Sun, Y.; Shi, X.; Zheng, X.; Nie, S.; Xu, X. Inhibition of dextran sodium sulfate-induced colitis in mice by baker's yeast polysaccharides. Carbohydr. Polym. 2019, 207, 371-381. [CrossRef]

31. Hwang, K.A.; Heo, W.; Hwang, H.J.; Han, B.K.; Song, M.C.; Kim, Y.J. Anti-Inflammatory effect of immature sword bean pod (Canavalia gladiata) in lipopolysaccharide-induced RAW264.7 Cells. J. Med. Food 2020, 23, 1183-1191. [CrossRef]

32. Li, S.T.; Dai, Q.; Zhang, S.X.; Liu, Y.J.; Yu, Q.Q.; Tan, F.; Lu, S.H.; Wang, Q.; Chen, J.W.; Huang, H.Q.; et al. Ulinastatin attenuates LPS-induced inflammation in mouse macrophage RAW264.7 cells by inhibiting the JNK/NF- KB signaling pathway and activating the PI3K/Akt/Nrf2 pathway. Acta. Pharmacol. Sin. 2018, 39, 1294-1304. [CrossRef]

33. Yang, C.; You, L.; Yin, X.; Liu, Y.; Leng, X.; Wang, W.; Sai, N.; Ni, J. Heterophyllin B ameliorates lipopolysaccharide-induced inflammation and oxidative stress in RAW 264.7 macrophages by suppressing the PI3K/Akt pathways. Molecules 2018, $23,717$. [CrossRef] 
34. Giridharan, S.; Srinivasan, M. Mechanisms of NF-kB p65 and strategies for therapeutic manipulation. J. Inflamm. Res. 2018, 11, 407-419. [CrossRef] [PubMed]

35. Xu, J.; Zhang, Q.; Li, Z.; Gao, Y.; Pang, Z.; Wu, Y.; Li, G.; Lu, D.; Zhang, L.; Li, D. Astragalus polysaccharides attenuate ovalbumininduced allergic rhinitis in rats by inhibiting NLRP3 inflammasome activation and NOD2-mediated NF- $\mathrm{K}$ B activation. J. Med. Food 2021, 24, 1-9. [CrossRef]

36. Kawai, T.; Akira, S. Signaling to NF-кB by Toll-like receptors. Trends Mol. Med. 2007, 13, 460-469. [CrossRef] [PubMed]

37. Souza, R.F.; Huo, X.; Mittal, V.; Schuler, C.M.; Carmack, S.W.; Zhang, H.Y.; Zhang, X.; Yu, C.; Hormi-Carver, K.; Genta, R.M.; et al. Gastroesophageal reflux might cause esophagitis through a cytokine-mediated mechanism rather than caustic acid injury. Gastroenterology 2009, 137, 1776-1784. [CrossRef] [PubMed]

38. Huo, X.; Agoston, A.T.; Dunbar, K.B.; Cipher, D.J.; Zhang, X.; Yu, C.; Cheng, E.; Zhang, Q.; Pham, T.H.; Tambar, U.K.; et al. Hypoxia-inducible factor-2alpha plays a role in mediating oesophagitis in GORD. Gut 2017, 66, 1542-1554. [CrossRef] [PubMed]

39. Jabri, M.A.; Tounsi, H.; Rtibi, K.; Marzouki, L.; Sakly, M.; Sebai, H. Ameliorative and antioxidant effects of myrtle berry seed (Myrtus communis) extract during reflux-induced esophagitis in rats. Pharm. Biol. 2016, 54, 1575-1585. [CrossRef]

40. Che, D.; Zhang, S.; Jing, Z.; Shang, L.; Jin, S.; Liu, F.; Shen, J.; Li, Y.; Hu, J.; Meng, Q.; et al. Macrophages induce EMT to promote invasion of lung cancer cells through the IL-6-mediated COX-2/PGE 2/ $\beta$-catenin signaling pathway. Mol. Immunol. 2017, 90, 197-210. [CrossRef] [PubMed]

41. Zhang, Z.; Wu, X.; Zhang, L.; Mao, A.; Ma, X.; He, D. Menthol relieves acid reflux inflammation by regulating TRPV1 in esophageal epithelial cells. Biochem. Biophys. Res. Commun. 2020, 525, 113-120. [CrossRef] [PubMed]

42. Akshay, B.; Martin, D.; Kay, R.-M.; Rohith, T.; Anthony, N.; Mutukumira, H.S. Chlorogenic Acid Potentiates the Anti-Inflammatory Activity of Curcumin in LPS-Stimulated THP-1 Cells. Nutrients 2020, 12, 2706.

43. Dipasquale, D.; Basiricò, L.; Morera, P.; Primi, R.; Tröscher, A.; Bernabucci, U. Anti-inflammatory effects of conjugated linoleic acid isomers and essential fatty acids in bovine mammary epithelial cells. Animal 2018, 12, 2108-2114. [CrossRef] [PubMed]

44. Saiki, P.; Kawano, Y.; Van Griensven, L.J.L.D.; Miyazaki, K. The anti-inflammatory effect of Agaricus brasiliensis is partly due to its linoleic acid content. Food Funct. 2017, 8, 4150-4158. [CrossRef] [PubMed] 